\title{
Cidade de Deus entre a história e a literatura: problemática racial no Rio de Janeiro (1960-1980)
}

\section{City of god among the history and literature: racial problem in Rio de Janeiro (1960-1980)}

\author{
Claércio Ivan Schneider ${ }^{1}$ \\ Camila Biranoski²
}

\begin{abstract}
Resumo
Busca-se, por meio da análise do romance "Cidade de Deus", de Paulo Lins, compreender as relações entre literatura e história, na tentativa de investigar o tema do preconceito racial no Rio de Janeiro, mais especificamente no conjunto habitacional Cidade de Deus. Em outras palavras, um dos principais objetivos deste texto é perceber na fonte literária de Lins as representações em torno da realidade de um determinado período e contexto histórico, no qual a marginalização, a exclusão e o preconceito racial são tematizados pelo autor a partir das relações sociais dos habitantes do conjunto habitacional.
\end{abstract}

Palavras-chave: Literatura. História. Racismo. Comunidade.

\begin{abstract}
This study analysis a novel wrote by Paulo Lins: "City of God" seeking to understand the relationship between literature and history in an attempt to investigate the subject of racial prejudice in Rio de Janeiro, more specifically in the housing complex called "City of God". In other words, one of the main goals of this paper is to identify in this literary source the representations of the reality of a given period and historical context in which Lins talks about the marginalization, the exclusion and the racial prejudice, based on the social relations of the inhabitants of the complex.
\end{abstract}

Keywords: Literature. History. Racism. Community.

Neste texto, tem-se por objetivo compreender as relações existentes entre a história e a literatura a partir da análise do romance "Cidade de Deus" (2002), de autoria de Paulo Lins. Busca-se historicizar a obra, problematizando um dos temas centrais da trama: o preconceito racial no Rio de Janeiro, dos anos de 1960 a 1980. Investindo na representação das relações conflituosas entre os habitantes que formaram o conjunto habitacional Cidade de Deus, Lins registra o cotidiano, utilizando-se, para tanto, da própria linguagem da população local residente na comunidade, constituída por afrodescendentes, nordestinos, brancos pobres e diversos outros tipos humanos.

\footnotetext{
1 Universidade Estadual do Centro-Oeste (UNICENTRO). Professor adjunto do Departamento de História da UNICENTRO, Campus de Irati/PR. E-mail: claercios@gmail.com.

2 Universidade Estadual do Centro-Oeste (UNICENTRO). Licenciada em História pela UNICENTRO. E-mail: camilabiranoski@yahoo.com.br.
}

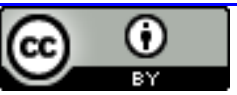

Esta obra foi licenciada com uma Licença Creative Commons - Atribuição 3.0 Não Adaptada. 
A obra escrita por Lins surgiu de um projeto antropológico, em conjunto com a antropóloga Alba Zaluar sobre "Crime e criminalidade no Rio de Janeiro". Morador da Cidade de Deus, Lins pesquisou a vida dos habitantes e se utilizou de sua própria experiência como morador para tais escritas. O livro foi publicado pela Editora Companhia das Letras, em 1997, e ganhou destaque pela forma poética e, ao mesmo tempo, realista manifestada. Primeiramente, a pesquisa seria destinada a uma dissertação de mestrado, inicialmente abrigada pela Unicamp, depois, pela UERJ. Portanto, a pesquisa não era tida como ficcionista, somente mais tarde se transformou em um romance de grande utilidade para análises históricas da contemporaneidade.

O livro, que narra a vivência no interior do conjunto habitacional Cidade de Deus, começou a ser escrito quando o autor ainda era um estudante. Em entrevista cedida ao jornal "Gazeta do Povo", Lins afirmou que, no momento em que o livro "Cidade de Deus" fez sucesso, foi vendido para as quatro grandes línguas do Ocidente: inglês, francês, italiano e espanhol. A editora, objetivando ganhar mais dinheiro, pediu a escrita de mais um livro para Lins; porém, o próprio autor respondeu que "Cidade de Deus" demorou uma década para ser escrita, dando ênfase à impossibilidade de escrever outro livro em dias, ou meses. Segundo Lins, no início da escrita, o projeto contou com mais de dez pesquisadores e mais de três mil entrevistados. Neste sentido, entende-se ser essa obra de grande importância para a análise da comunidade, e dos habitantes lá existentes. Os temas presentes em "Cidade de Deus" não se resumem somente às questões raciais, foco desta pesquisa, mas em fatores como prostituição, miséria, desemprego, assassinato, tráfico, etc. O autor apresenta a realidade do bandido, dos indivíduos desprovidos de voz e de vez na sociedade.

Os episódios presentes na trama montada por Lins narram acontecimentos correspondentes às décadas de 1960, 1970 e 1980, vivenciadas pela população residente na comunidade, em sua maioria afrodescendente. Estes viviam em precárias condições de vida, resultado direto de sua pobreza, do analfabetismo e das péssimas condições de moradia, mas sonhavam um dia melhorar de condição, principalmente econômica. Conscientes da exploração que sofriam, negavam se sujeitar às condições impostas pelos donos de fábricas, principalmente os pequenos salários recebidos em troca de uma longa jornada de trabalho. Neste sentido, por meio dos roubos, tráfico de drogas e de armas, buscavam solucionar seus problemas econômicos, não se sujeitando às imposições da elite.

A partir da análise da narrativa literária de Lins procuramos destacar, analisar e problematizar, dentre um universo ilimitado de temas, a representação que o autor 
constrói acerca dos preconceitos raciais e das condições de discriminação. Mais especificamente, intenta-se compreender as caracterizações acerca da população afrodescendente que habitava a comunidade, analisando as discriminações presentes nas relações entre os próprios sujeitos da comunidade.

As relações preconceituosas no Rio de Janeiro se manifestam já antes do período imperial, no qual estereótipos raciais foram construídos por uma elite administrativa, que buscava denegrir a condição do escravo, identificando-o como um animal irracional. Com a abolição, os preconceitos, os estereótipos e as discriminações continuaram e, ainda hoje, nas décadas posteriores às descrições de Lins, de 1960 a 1980, as relações preconceituosas representam um problema de difícil solução, pois estão arraigadas à mentalidade. Na obra em questão, os preconceitos de cunho racial são analisados por meio das manifestações e das sociabilidades presentes em um contexto específico de formação das periferias, como é o caso da "Cidade de Deus".

A visão oficial, transmitida desde fins do século XIX, de que o afrodescendente não era símbolo de beleza, nem de abundância, permeava a mente dos "racistas" de cor branca, em sua maioria pertencentes à classe média ou à elite. Assim, quanto mais afastados dos centros urbanos estivessem os afrodescendentes, melhor seria para as classes médias e altas. Nesse sentido, as periferias, lugares mais afastados, tornaram-se o habitat da nova classe liberta da escravidão, desde 1888. As difíceis condições de vida continuaram a ser uma realidade presente em seus cotidianos, sendo que o crime, 0 tráfico e os roubos, na maioria das vezes, eram as formas encontradas por muitos deles para enfrentar as situações de miséria do dia a dia.

Segundo o mencionado acima, o afastamento de comunidades pobres era fundamental para o embelezamento e a ideia de segurança das cidades. A construção da comunidade, mais tarde transformada em favela, foi um exemplo de tentativa de embelezamento do centro urbano e da exclusão dos afrodescendentes desse espaço. Segundo Santos e Lima, (2008, p. 3), "Cidade de Deus" foi construída a partir da junção de vinte e três favelas em um só lugar. Segundo essas autoras, as favelas eram próximas a centros urbanos do Rio de Janeiro, e foram removidas em consequência da urbanização e da estilização.

As desigualdades raciais da comunidade, tema considerado de grande relevância para a compreensão da formação social do Rio de Janeiro, parecem atualizar as discussões que, no final do século XIX, foram tematizadas por Aluízio de Azevedo em "O cortiço", no qual os preconceitos se exacerbam com a aglomeração em favelas. 


\section{Os caminhos da história no diálogo com a literatura}

Adan (2008, p. 1) comenta, no artigo intitulado "A literatura como evidência histórica: cotidiano popular em 'O Cortiço'” (1890), sobre a consolidação da história como ciência. Na segunda metade do século XIX, os historiadores começaram a escrever a história, acreditando no registo dos acontecimentos do passado, como se realmente correspondessem ao acontecido. Era uma história baseada e dependente dos documentos, tratava-se de realizá-la com o objetivo de exaltar os grandes heróis, apontando para a preocupação com as identidades nacionais. Esse autor destaca a importância dos Annales (1929) para o surgimento de novos pensamentos intelectualizados: "inaugura-se, por fim, uma nova crítica documental fundada no diálogo com as fontes, inquirindo-as conforme os problemas de investigação colocados pelo pesquisador" (ADAN, 2008, p. 2).

A partir da década de 1970 alguns historiadores começaram a agir como defensores da interdisciplinaridade presente entre as narrativas históricas e literárias. White, Pesavento, Lemaire, entre outros autores, promovem a discussão no campo acadêmico, oferecendo noções e conceitos importantes para que no campo da história se possa trabalhar com a fonte literária:

Se antes as fontes literárias ocupavam lugar secundário, quase ilustrativo, na historiografia, elas adquirem agora estatuto de fontes primárias, autônomas, representações do passado que devem ser tratadas em suas especificidades (ADAN, 2008, p. 4).

Desde então, assumiu-se que a história é constituída de elementos literários, principalmente em virtude da sua narrativa, e que as obras literárias são constituídas de elementos históricos, até porque, mesmo sem a preocupação com a realidade em si, na maioria das vezes, os autores se pautam nos aspectos do cotidiano de determinados contextos históricos. Para desenvolver suas tramas no discurso histórico, o profissional da história utiliza elementos considerados científicos - a seleção das fontes, a aplicação do método, a busca pela verdade - e, ao mesmo tempo, ficcionais - a imaginação e a interpretação, por exemplo, constituintes da subjetividade de cada historiador.

Para Borges (2010), a literatura evidencia aspectos do campo social, ao qual se refere em determinados escritos, romances, poemas, contos, tragédias e novelas. Muitas vezes, esses espaços sociais se apresentam conflituosos e diversificados, pois as sociedades são distintas, bem como as formas de pensar que permeiam o interior das 
comunidades. Voltados para essa questão, vejamos o que o autor diz a respeito da arte literária:

\begin{abstract}
É testemunha efetuada pelo filtro de um olhar de uma percepção e leitura da realidade, sendo inscrição, instrumento e proposição de caminhos, de projetos, de valores, de regras, de atitudes, de formas de sentir [...]. Enquanto tal registro é leitura, interpretação do que existe e proposição do que pode existir e aponta a historicidade das experiências de invenção e construção de uma sociedade com todo seu aparato mental e simbólico (BORGES, 2010, p. 5).
\end{abstract}

Os literatos, muitas vezes, interpretam o campo do social, as realidades presentes em determinados lugares, de uma forma considerada imagética pelos receptores, mas que, se analisada com olhares voltados para o contexto em que a obra foi produzida, podemos perceber aspectos culturais, políticos e econômicos de um ou mais grupos de humanos. Para Borges (2010, p. 5), é indispensável refletir sobre as características das formas de ficção das relações que os textos literários têm em particular, como as aproximações ou descrições do convívio diário de pessoas em seu grupo.

Embora a criação da arte literária tenha como elemento principal a imaginação do autor, ela não provém de um mundo totalmente fantasioso, uma vez que a escrita do romancista representa elementos do mundo que o cerca, identificando escolhas, representações, valores e ideias que dão sentido à dramatização. O historiador, por sua vez, faz uso dos documentos, de historiografia e de métodos, a fim de chegar o mais perto possível da realidade. Considerando a importância da história ficcionista, Pesavento (1999) adverte quanto à noção de história verdade, por considerar não ser a história mimese do acontecido de tempos atrás. Segundo ela, a presença de um narrador, de fatos ouvidos ou presenciados, é fundamental para a escrita de uma nova história (PESAVENTO, 1999, p. 819).

A história não deixa de ser ficção e, assim como os literatos, os historiadores imaginam fatos não presenciados, precisam formar imagens de acontecimentos de muito tempo atrás. É necessário imaginar as formas de pensar e de sentir de épocas passadas, tomando cuidado com o risco de cometer anacronismos, ou seja, analisar épocas passadas com os valores do presente. Para tanto, precisa levar em consideração a época em que a obra literária se inscreve, em que foi escrita, o autor, sua vida, suas formas de pensar e seus objetivos.

Pesavento (1999) afirma que a história, quando baseada em uma vasta documentação, é uma ficção, mas não uma ficção no sentido imaginativo total, porque o historiador pesquisa e coleta determinado número de dados para seu trabalho. A essa vasta pesquisa, Pesavento (1999) usa o termo "ficção controlada", ou seja, a escrita é 
controlada pelo depoimento oral, por um documento antigo e pelos métodos de análise selecionados, e que tem como objetivo apresentar uma verdade possível. Segundo a autora:

Ficção controlada, porque a história aspira a ter, em sua relação de "representância", com o real, um nível de verdade possível. Se não mais aquela verdade inquestionável, única e duradoura, um regime de verdade que se apoie num desejável e íntimo nível de aproximação com o real (PESAVENTO, 1999, p. 820).

Para Lemaire (2000), os fatos históricos do passado podem ser recuperáveis, graças à existência de documentos, mas estes não são "os próprios fatos brutos concretos" (LEMAIRE, 2000, p. 10). Esses resquícios são apenas representações de acontecimentos do passado, irrecuperáveis em sua total veracidade. Vejamos o que nos diz Lemaire (2000) a respeito das "diferenças" entre as duas disciplinas, ambas consideradas por ela imagináveis.

\begin{abstract}
História e literatura reconfiguram um passado. Trata-se, no caso da História de uma reconfiguração "autorizada", circunscrita pelos dados fornecidos pelo passado (as fontes), pela preocupação da investigação sobre documentos, pelos critérios e exigências científicas do método. A literatura, ao contrário, permite que o imaginário levante voo mais livre e amplamente que ele fuja, numa certa medida, aos condicionamentos impostos pela exigência da verificação pelas fontes (LEMAIRE, 2000, p. 11).
\end{abstract}

História e literatura são narrativas, porém, para a escrita da História, faz-se necessário, como mencionam as autoras acima, a existência de documentos. A Literatura, ao contrário, depende, em maior grau, da imaginação do autor. O historiador Hayden White (2001) define a disciplina histórica de forma semelhante às autoras já mencionadas. Segundo ele, existe uma relutância, por parte dos historiadores, em considerar aquilo que as narrativas históricas realmente manifestam. E essas manifestações nada mais são que ficções verbais, cujos conteúdos são tanto inventados quanto descobertos, e ainda as formas da História têm mais equivalência com a prática literária do que com as ciências em geral. Segundo White (2001), os historiadores precisam fazer uso de figuras de linguagens distintas em suas escritas, a exemplo da metonímia, da ironia, do sarcasmo, da sinédoque, da tragédia. Em suas palavras:

A meu ver, a história como disciplina vai mal atualmente porque perdeu de vista as suas origens na imaginação literária. No empenho de parecer científica e objetiva, ela reprimiu e negou a si própria sua maior fonte de vigor e renovação. Ao fazer a historiografia recuar uma vez mais até a sua íntima conexão com sua base literária, não devemos estar apenas nos resguardando contra distorções simplesmente ideológicas; devemos fazê-lo no intuito de chegar àquela "teoria" da 
história sem a qual não se pode de maneira alguma considerá-la "disciplina" (WHITE, 2001, p. 14).

A crise da história na contemporaneidade é atribuída por White ao descompromisso dos historiadores com a imaginação literária. $\mathrm{O}$ alto grau de cientificidade da história reprime sua renovação. Reestabelecendo a conexão da história com sua base literária, pode-se investir na análise dos tropos do discurso, pois a história não deixa de ser também, em si, ficção. A história é permeada por elementos da imaginação de quem a escreve.

Trabalhar com obras literárias implica encontrar os pontos relacionados à realidade histórica de um espaço temporal e de uma determinada cultura. Assim consideramos a grande importância de citarmos as palavras de Chalhoub e Pereira (1998):

A proposta é historicizar a obra literária - seja ela conto, crônica, poesia ou romance - inseri-la no movimento da sociedade, investigar as suas redes de interlocução social, destrinchar não a sua suposta autonomia em relação à sociedade, mas sim a forma como constrói ou representa a sua relação com a realidade social - algo que faz mesmo ao negar fazê-lo (CHALHOUB; PEREIRA, 1998, p. 7).

Conforme enfatiza Pesavento (2003, p. 9), a literatura pode ser usada como fonte histórica, desde que os objetivos do historiador não estejam pautados em desvendar datas, fatos ou nomes de acontecidos, já que essa tarefa se reserva mais especificamente à história. Nossa pesquisa objetiva analisar as formas de pensar dos habitantes de Cidade de Deus, bem como suas condições de vida, seus sentimentos e seus anseios. Neste caso, a literatura foi muito útil para Paulo Lins apresentar aspectos condizentes com a realidade daquele período histórico.

\section{Situações de preconceitos raciais na Cidade de Deus}

Odiavam a vida de empregada doméstica, no fundo uma vida de desprezo, trabalho pesado e dinheiro curto. Nostálgica sempre dizia que não seria a palmatória do mundo porque não tivera todas as coisas que um ser humano precisa para se afirmar na vida, não fora ela quem inventará o racismo, a marginalização e nenhum outro tipo de injustiça social; não tinha culpa de ter largado os estudos para dar brilho no chão de casa de madame. Queria dinheiro para dar uma vida digna aos filhos, coisa que trabalhando não conseguiria, e por isso a cada final de mês, assim como as demais, fazia de trinta a quarenta investidas nos mercados, sempre alcançando resultado positivo. Tiveram dinheiro para médico, dentista, alimentação e para o material escolar dos filhos. Não queriam mais do que uma vida digna, e por isso aumentaram as minúsculas casas que moravam, repuseram no lugar os móveis levados pela enchente. Passaram a se vestir decentemente e a alimentar-se bem, a usar os tão sonhados cosméticos [...]. A aparência de cada uma mudou, facilitando ainda mais a atividade delas, que perdurou por muito tempo (LINS, 2002, p. 217). 
A partir dessa descrição de Lins, retratando a vida de mulheres que investiram no crime, percebemos que o discurso da democracia racial no Brasil é um mito. As mulheres afrodescendentes, personagens do livro analisado, mostram-se revoltadas, porque a elas foram reservadas as tarefas domésticas em casas de "madames", a baixas remunerações. Situação que se complica ainda mais devido à precariedade da educação em Cidade de Deus, pois a falta de estudos torna essas mulheres sempre submissas a seus patrões. Além disso, essa população, em sua maioria afrodescendente, era desprovida de rede de esgoto, água encanada, luz elétrica, enfim, o fundamental para a sobrevivência humana. Conscientes do estereótipo racista, mostram revolta e indignação com sua condição de excluídas. Conforme destaca Lins, várias vezes, no romance, os habitantes de Cidade de Deus, inconformados com as condições de vida, apelavam para meios próprios de resolver as situações cotidianas, muitas vezes partindo para a criminalidade e para a violência.

Obrigavam-se, por isso, a encontrar formas próprias de suprir suas necessidades básicas, mesmo que isso implicasse investidas nos mercados. Weber (2005, p. 273) ajuda a desvendar o cotidiano dessa comunidade. Segundo ele, os correios somente entregavam as cartas para as primeiras casas localizadas no início das favelas, sendo os moradores destas responsáveis por reenviá-las aos demais. A água e a luz eram adquiridas por meio de extensões ilegais. O sistema de saúde também era bastante precário, pois os médicos e ambulâncias não eram suficientes. Como afirma Barcellos (2000, p.130): "se a doença é uma manifestação do indivíduo, as condições de vida são manifestação do lugar".

A citação que introduz este item diz respeito à revolta das mulheres de Cidade de Deus, também insatisfeitas com a marginalização, com o racismo e com a injustiça social. Elas se sentem injustiçadas ao olhar para as madames da alta sociedade e, assim como os bandidos, apelam para o furto. Lins, embora imbuído de ficção em sua forma de narrar, traz inúmeras questões referentes ao preconceito racial, em um espaço do Rio de Janeiro. Ele mostra, de forma sucinta, os sentimentos dessas pessoas em relação à sociedade em geral, sentimentos que mostram a consciência de sua condição histórica.

A população afrodescendente é vista como protagonista para narrar histórias de amor e ódio, de violência e tolerância, de práticas criminosas e de sociabilidades, que conferem a esse contingente um retrato múltiplo para a compreensão de seus papéis sociais. Assim, preconceitos, injustiças, crimes e indiferenças se constituem em temas de estudo, para identificar e analisar a situação social dos moradores do conjunto habitacional de Cidade de Deus, entre os anos de 1960 a 1990. 
Baseando-nos nessas situações de estereótipos raciais, analisemos as palavras de Costa (1984):

\begin{abstract}
O negro sabe que o branco criou a inquisição, o colonialismo, o imperialismo, o antissemitismo, o nazismo o stalinismo e tantas outras formas de despotismo e opressão ao longo da história. $O$ negro também sabe que o branco criou a escravidão e a pilhagem, as guerras e as destruições, dizimando milhares de vidas. O negro sabe igualmente que, hoje como ontem, o branco condenou e condena milhões e milhões de seres humanos à mais abjeta e degradada miséria física e moral (1984, p. 4).
\end{abstract}

Costa (1984) nos traz situações similares às relatadas literalmente por Lins, quando considera o afrodescendente como desprovido de culpa pela sua miséria. São homens e mulheres que não habitam locais afastados e precários economicamente por vontade própria ou por se sentirem bem, diante de tais realidades, mas que são vítimas de todas as situações descritas acima. Esse mesmo autor refere-se à brancura como algo mistificado na mente de habitantes de comunidades como Cidade de Deus, em que o branco é tido como sinônimo de beleza artística, nobreza estética, majestade moral, sabedoria científica etc (COSTA, 1984, p. 4). Talvez por isso, busca-se afastar dos centros urbanos esse contingente marginalizado e estigmatizado pela cor, e reprimi-los a partir da violência racial.

O conjunto habitacional Cidade de Deus surgiu da decisão do governo da época, de Carlos Lacerda, em remover favelas próximas aos centros urbanos para lugares mais afastados. Nesse sentido, a exclusão se manifestou bastante clara, mas o processo de formação, ao contrário de outras favelas, não ocorreu com uma ocupação irregular, uma vez que foi construído pela prefeitura do Rio de Janeiro para dar abrigo a grupos de familiares que haviam perdido suas moradias, em 1960, em consequências de fortes enchentes. Nas páginas iniciais do romance, Lins (2002, p. 17) afirma existir apartamentos e casas construídos pela prefeitura, e que, diante de tal iniciativa, a aglomeração de pessoas foi inevitável, provocando todos os problemas narrados no romance.

Nas várias passagens da obra, o autor menciona inúmeras situações de conflitos raciais enfrentados pela população afrodescendente. Estes, embora desprovidos de educação de qualidade, apresentam um pensamento crítico em relação às situações enfrentadas no dia a dia, como percebemos na revolta das mulheres ao roubar os mercados. Nesse sentido, ao virar as páginas do romance, nos deparamos com a revolta dessa população, que clama por direitos iguais e melhores condições de vida, sendo, na grande maioria das vezes, reprimida. 
Diante dos fatos narrados por Lins, a questão do preconceito racial se encontra também evidente entre os próprios moradores do conjunto habitacional. No entanto, compreende-se que essa realidade resulta de uma série de acontecimentos do passado, anteriores à formação da comunidade, como a escravidão, as reformas urbanas e a abolição. Frente às questões de inferioridade racial, presentes nas entrelinhas, a obra traz exemplos do afrodescendente estereotipado.

Para melhor compreender essa problemática racial, é fundamental entender o contexto histórico de fins do século XIX. Naquele período, a população escrava estava cada vez mais revoltada com a condição de subordinação. As revoltas eram constantes, e a abolição da escravidão se tornou inevitável, em 1888. Mas, a liberdade cedida aos escravos, em sua grande maioria de origem africana, não foi uma liberdade em si, os escravos não ganharam nenhuma gratificação ou propriedade pelo tempo trabalhado, mas foram entregues à própria sorte. Grande parte dos proprietários de fazendas os expulsaram, buscando se desonerar do compromisso com vestimenta, alimentação e moradia. O número de pessoas livres e sem moradia se tornou excessivo, muitos se aglomeraram em cortiços. Então, para sobrevivência, parte dessa população começa a praticar pequenos delitos, trabalhos informais e práticas ilegais, o que se evidencia no estereótipo do malandro carioca.

Sempre perseguida pelas reformas sanitaristas, grande parte desse contingente de ex-cativos obrigava-se a procurar os lugares mais afastados da cidade para construir pequenas casas ou barracos. Muitas vezes, os administradores públicos os enviavam à força para os locais afastados dos grandes centros urbanos, como pode ser percebido no episódio da reforma promovida por Pereira Passos. Percebe-se, nas entrelinhas do romance, que essas questões do passado histórico são determinantes na constituição social do Rio de Janeiro. Em relação à formação do conjunto habitacional Cidade de Deus, Sarmento destaca:

\footnotetext{
Cidade de Deus foi construída num projeto de Carlos Lacerda no governo federal nos anos de 1960, este governo destacou-se pela construção de grandes obras que mostraram suas habilidades de administrar e consolidaram a simpatia da classe média por remover favelas e bairros da Zona Sul e Maracanã, instalando seus antigos habitantes em conjuntos habitacionais afastados como Cidade de Deus e Vila Kennedy (SARMENTO, 2011, p. 3).
}

A remoção das favelas do centro do Rio de Janeiro agradava a elite. Política oficial desde fins do Império, essa atitude de retirar do centro os indivíduos indesejados, estereotipando-os por sua pobreza e descendência, solidifica um ambiente de preconceitos que corroboram com o aumento da violência. Nesse sentido, as formas de 
exclusão descritas por Lins levam determinados habitantes da Cidade de Deus principalmente crianças - a ver no tráfico de drogas e no crime meios de superação das condições precárias às quais foram submetidos. A violência se transforma em conquista de prestígio e de temor por parte da população aglomerada no conjunto.

Como já mencionado, a formação da favela resultou do deslocamento de várias pessoas de outras regiões fluminenses. Pessoas pobres, mas providas de desejos de melhorar suas condições de vida. Indiretamente, Lins (2002) relata que os "descendentes de africanos" enfrentam situações de discriminação racial, sendo a periferia um dos únicos lugares reservados. Essas condições de estereótipos raciais, sobre os quais discorremos, não são somente da população branca para com a população afro-brasileira. No interior da favela, Lins aponta casos de preconceitos entre os próprios habitantes, como é o caso do personagem traficante Pardalzinho.

\footnotetext{
O sonho de Pardalzinho era o de comprar um terreno onde tivesse água corrente, terra boa para o cultivo e pequenas casas de madeira para ele e os cocotas morarem. Era isso o que deveria fazer para viver entre pessoas de rostos límpidos por não conviverem cara a cara com a morte. Nunca pensavam em matar ninguém embora gostassem de maconha como ele. Era esse o seu sonho ganhar uma mina bonita, morar entre gente bonita e dançar discoteca até o fim da vida, numa boa. Nada daqueles crioulos com cara nervosa e sem dentes (LINS, 2002, p. 271).
}

Percebe-se na citação acima a insatisfação com a condição a que Pardalzinho se via submetido. Ele era um dos traficantes da Cidade de Deus. Revoltado com as condições de pobreza do conjunto, ele não aceitava ser pobre, excluído, enquanto os "cocotas" eram brancos e da classe média. Assim sendo, acreditava que, convivendo entre as pessoas de "rostos límpidos", seria mais feliz. Estando longe da criminalidade, fumaria maconha, teria uma namorada bonita e não precisaria mais conviver com os demais traficantes. Mesmo no interior da favela, os moradores enfrentam condições de preconceitos entre eles próprios, ao observar que, aparentemente, era menor o número de brancos que sofriam os mesmos preconceitos.

Acredita-se que esses fatos históricos, inerentes à trama do romance, são evidentes para caracterizar que a cor das pessoas e suas condições sociais aparecem como questões principais para a exclusão e para a marginalização dessa população. Os habitantes da Cidade de Deus encontram difíceis condições de sobrevivência, dando-nos a entender, de forma muito nítida, o que diversas vezes Lins menciona como herança de quase três séculos de escravidão, no Brasil. Na citação a seguir, o autor enfatiza a questão dos conflitos raciais, ocasionados pela insatisfação dos descendentes de 
escravos. Essa fala é de um traficante, o Grande, fugitivo da polícia, um homem de quase dois metros de altura que, segundo Lins (2002), deixa qualquer bandido com medo:

Tinha prazer em matar branco, porque o branco tinha roubado seus antepassados da África para trabalhar de graça, o branco, criou a polícia para bater, prender e matar o negro. Tudo o que era bom era dos brancos. O presidente da república era branco, o vovô viu a uva do livro de leitura da escola era branco, os ricos eram brancos, as bonecas eram brancas (LINS, 2002, p. 176).

Lins representa falas que demonstram a consciência da condição de inferioridade delegada aos afrodescendentes, sentimento de indignação e de perseguição. Representações similares a essa são comuns em várias passagens do texto literário, pois, como diz Lins, os "malandros" estão indignados com a situação de miséria na qual se encontram. O principal objetivo desses habitantes é, segundo suas palavras, "encontrar a boa", seja por meio de um grande assalto ou através do comércio de drogas e de armas. "Encontrar a boa" quer dizer se assemelhar aos brancos ricos dos grandes centros urbanos, ou melhor, ser como eles (LINS, 2002, p. 43).

Vejamos como o autor Lins retrata a vida de um dos personagens chamado Inferninho, membro de família desestruturada, que passou a ganhar seu sustento por meio dos assaltos e do tráfico de drogas, assim como os demais traficantes. Após assaltar um caminhão de gás com os colegas Tutuca e Martelo, Inferninho começa a lembrar de sua família, o pai era bêbado, a mãe trabalhava na zona, mas, para ele, o maior problema era seu irmão Ari, que era homossexual (LINS, 2002, p. 23). Nesse contexto, vejamos a revolta de Inferninho quando a sua avó morre vítima de incêndio:

[...] Lembro-me também daquela safadeza do incêndio quando aqueles homens chegaram com saco de estopa ensopado de querosene botando fogo nos barracos, dando tiro para todos os lados sem quê nem para quê. Fora nesse dia que sua vovó rezadeira, a velha Benedita morrera queimada. Já não podia sair da cama por causa daquela doença que a obrigava a viver deitada. "Se eu não fosse molequinho ainda, pensava Inferninho, "eu tirava ela lá de dentro a tempo e, quem sabe, ela estava aqui comigo hoje, quem sabe eu era otário de marmita e o caralho, mas ela não ta, morou? "To ai pra matar e pra morrer". Um dia após o incêndio, Inferninho foi levado para a casa da patroa da sua tia. Tia Carmem trabalhava no mesmo emprego havia anos. Inferninho ficou morando com a irmã da mãe até o pai construir outro barraco no morro ficava entre o tanque e a pia o tempo todo e foi dali que viu, pela porta entre aberta, o homem do televisor dizer que o incêndio fora acidental, sentiu vontade de matar toda aquela gente branca, que tinha telefone, carro, geladeira, comia boa comida, não morava em barraco sem água e sem privada. Além disso, nenhum dos homens daquela casa tinha cara de viado como o Ari. Pensou em levar tudo da brancalhada, até o televisor mentiroso e o liquidificador colorido (LINS, 2002, p. 23).

Lins conduz o leitor a refletir sobre os problemas de ordem social existentes em Cidade de Deus. Inferninho culpa as pessoas brancas por sua condição econômica. 
Mostra revolta e age roubando os bens, que davam aos ricos brancos o conforto que nunca teve. Como o autor mostra em passagens anteriores, Inferninho representa muitos habitantes da vida real. Apesar da desestrutura familiar, ele pensava poder superar, e até mesmo conseguir um bom trabalho, mas a forma como os brancos atuavam na sociedade, o fez desistir de ser trabalhador honesto, levando-o a ingressar na vida do crime. Sua insatisfação era com as pessoas de classe média ou alta, que recebiam mais atenção do Estado, quanto a saneamento básico, abastecimento de água, luz elétrica, proximidade das escolas, entre outros aspectos.

O exemplo de Inferninho pode ser percebido em outras personagens colocadas em cena por Lins em Cidade de Deus. A malandragem, pouco a pouco, vai substituindo a obediência às regras impostas pela sociedade. As revoltas surgem devido à busca por melhores condições econômicas e por reconhecimento, por afirmação, principalmente entre a própria comunidade. Os traficantes caracterizados por Lins, parecem se sentirem inferiores aos brancos, ou com a impressão de que nunca poderiam ser iguais a eles: "se eu chegar igual moça, nego deita e rola, ta sabendo? Todo mundo aqui tem cara de bandido, quase não tem branco nesta terra só tem crioulo mal encarado. Não vou dar sopa mermo!" (LINS, 2002, p. 35). Nessa passagem, Lins se refere a uma conversa com o dono de um clube de bailes noturnos e com os policiais que constantemente seguiam a bandidagem. Na visão desses policiais, os brancos eram os trabalhadores e os afrobrasileiros representavam um perigo para a sociedade, por isso era necessário prendêlos. Nessas circunstâncias, percebe-se a ação dos aparelhos repressivos do Estado. Através da repressão, esses policiais objetivavam inibir indivíduos que se colocam contra as leis do Estado.

Lins mostra que a bandidagem crescia vertiginosamente em Cidade de Deus ao longo das décadas. A recusa em trabalhar por salários irrisórios para os brancos dos grandes centros urbanos auxiliava nas decisões particulares: ganhar a vida como bandido, orgulhando-se de desobedecer a ordem vigente, como no caso de Inferninho. Este, segundo a narrativa literária, desde criança gostava de cumprimentar a bandidagem, fazia favores como enrolar maconha, limpar as armas, em que, muitas vezes, comprava até mesmo querosene com seu próprio dinheiro para a limpeza das armas. Percebemos, assim, que, desde sua infância, ele já estava insatisfeito com sua condição econômica e familiar, mas, na medida em que vai crescendo, ele adentra cada vez mais no mundo do crime, sempre objetivando "ganhar a boa" (LINS, 2002, p. 43): 
receber ordens dos branquelos, ficar sempre com o serviço pesado sem chance de subir na vida, acordar cedão para pegar no batente e ganhar merreca. Na verdade a morte da avó serviu somente de atenuante para seguir o caminho no qual seus pés já haviam dado os primeiro passos, porque, mesmo se a avó não morresse assassinada, seguiria o caminho que para ele significava não se submeter à escravidão. Não, não seria otário de obra. Deixava essa atividade, de bom grado, para os paraíbas que chegavam aqui morrendo de sede. No terceiro assalto teve de trocar tiro com a polícia, mas deu a sorte de sair ileso, sentiu vontade de se arrebentar na obra, mas que nada, bandido que é bom da sorte. Um dia, ganharia a boa (LINS, 2002, p. 43).

Muitas situações são similares às vivenciadas por Inferninho. A condição de trabalho imposta pelos "branquelos" é tida como extenuante, cansativa e pouco lucrativa, pois o salário mínimo atendia somente às necessidades básicas. Inferninho se refere também à escravidão. Em sua visão, trabalhar nas grandes construções e empresas é se sujeitar ao escravismo vivenciado por seus antepassados. A resistência às precárias condições de vida generalizava cada vez mais as situações de violência em Cidade de Deus.

O preconceito racial também transparece entre as diferenças regionais. Na obra, tem-se a impressão de que os paraibanos não se importavam em trabalhar para ganhar o sustento, mesmo na forma de baixos salários, porém a violência e a resistência da população da favela com sua presença os incomodavam. Em várias passagens, nordestinos eram mortos pelos malandros da comunidade Cidade de Deus devido à discordância de ideias. Vejamos, a seguir, uma situação em que o paraibano resolve entregar bandidos para a polícia, mostrando certo ódio pelos moradores da comunidade. Ele migrou para o Rio de Janeiro à procura de trabalho; após conseguir uma casa, ele manda uma carta para sua família no nordeste pedindo para que migrassem também. Devido ao fato de ter sido assaltado por afro-brasileiros mais de uma vez, começou a implicar com os afrodescendentes da comunidade, e na primeira oportunidade denunciou os bandidos para a polícia:

Francisco não teve nenhum medo de acenar para os policiais civis de ronda a fim de alcaguetar naquela mesma noite em que prometera vingança aquela raça maldita. Dizia sempre que já não gostava de crioulos e que depois que veio para o Rio passara a sentir raiva. Argumentava com os amigos que o loiro era filho de Deus, o branco Deus criou, o moreno era filho do bastardo, e o preto o Diabo cagou. Ter informado à polícia a casa de Martelo foi sua grande vingança aquela raça de picolé de asfalto (LINS, 2002, p. 53).

O nordestino Francisco não hesitou em entregar os bandidos para a polícia, buscando vingança. Já trazia consigo o preconceito contra os moradores. Fundamentavase em Deus. Dias depois foi morto pelos traficantes da Cidade de Deus. 
No romance "Cidade de Deus", literatura e história formam um emaranhado de ideias na mente do leitor. Os acontecimentos e os fatos narrados por Lins chocam muitos leitores, principalmente quanto às cenas de violência. A fim de representar acontecimentos internos da favela, o autor, usando-se da linguagem própria da bandidagem, revela um ambiente tenso, marcado por ressentimentos, que se expressam no preconceito.

Vejamos, nas palavras de Lins, uma passagem da vida de um dos traficantes descendentes de ex-escravos. Nela, nota-se a presença do samba, ritual trazido para o Brasil pelos africanos.

Pelé nasceu no morro do Borel. O pai, que se dizia neto de escravos, era um homem forte, bonito, trabalhava de lixeiro, bebia somente nos fins de semanas; nos dias de trabalho preferia fumar um bagulhinho nas quebradas do morro, onde sempre fora respeitado pela malandragem e pelos bandidos. Passista da Unidos da Tijuca, lateral direito do Evereste, time da segunda divisão, Cibalena sempre foi assediado pelas mulheres da escola de samba, da torcida do time em que jogava e do morro onde residia. Tinha orgulho de falar nas rodas de amigos que tinha filhos que nem ele conhecia, mas eram as mulheres as culpadas, pois na expectativa de segurá-lo para sempre deixavam-se engravidar por pura picardia (LINS, 2002, p. 95).

Pelé, segundo Lins, com quinze anos de idade, já era um bandido feito. Procurava seu pai, Cibalena, mas este o rejeitava. Sua mãe o criou sozinha, pois foi expulsa da casa dos pais, quando estes descobriram sua gravidez. A única saída foi ganhar a vida como prostituta, ainda grávida de Pelé. Com o passar do tempo, começou a roubar como as demais mulheres. O menino Pelé foi crescendo, e quando descobriu que a mãe era prostituta nunca mais falou com ela; quanto à escola, ele nunca frequentou. Essa é uma triste realidade da maioria das crianças. Já na infância são persuadidas a seguir os demais bandidos, sem chances de estudar e obter conhecimento para melhor realizar suas escolhas.

Grande parte dos moradores da Cidade de Deus, como já mencionado, são descendentes dos povos trazidos da África. Nesse sentido, além do samba, a religião também foi herdada da cultura africana. Na citação abaixo, veremos uma passagem em que os moradores se reúnem para comemorar o primeiro dia do ano, e agradecer ao orixá Xangô, orixá do candomblé:

O primeiro minuto do ano novo chegou. Ano de Xangô, o vencedor de Demandas, orixá mais poderoso, deus dos raios e do fogo, o rei da justiça. Era o ano de lutar por um amor seguro, saúde e muito dinheiro. Quem fosse justo teria sucesso naquele ano. Ainda era dia quando as pessoas disputavam lugares nos ônibus para ir à praia criar uma primavera em pleno verão na noite e no mar. Flores dispostas a fazer novas correntezas na vida de todos os filhos do pai Xangô. Cantavam pontos para todos os orixás, saravando diante das águas de lemanjá. 
Soltavam fogos para salvar Xangô justiceiro, milhões de cores para imitar seu brilho e muitas orações para agradecer sua proteção (LINS, 2002, p. 78).

Essa cultura religiosa de grande parte dos habitantes da Cidade de Deus também auxilia no distanciamento da cultura oficial, em sua maioria católica, pois o candomblé, de procedência africana, geralmente é visto de forma negativa e preconceituosa.

O caso de Martelo, bandido da Cidade de Deus, é similar à situação acima, pois ele se converte à religião evangélica, acreditando ser esta a solução para seus problemas. No início, ele era um homem como os demais da comunidade, insatisfeito com o trabalho pesado. Sob a ordem do patrão, ele ganhava a vida roubando, traficando drogas. Tempos depois, dominado pelo medo de ser morto, tornou-se evangélico, o que, pela lógica, implica no abandono da antiga fé em Exu. Analisemos, primeiramente, em uma passagem de Lins, o momento em que ele era bandido e insatisfeito com a condição econômica. Essa passagem trata de uma conversa com sua esposa, Cleide. Ela pedia para ele deixar a vida do crime, mas ele negava:

\begin{abstract}
Calaram-se, porém Martelo lembrava das balas que já haviam passado zunindo em seus ouvidos, das vezes em que quase dançara durante as fugas. Realmente, tinha medo de amanhecer com a boca cheia de formigas, mas virar otário na construção civil, jamais. Esta onda de comer de marmita, pegar ônibus lotado para ser tratado que nem cachorro pelo patrão, não, isso não. Recordou-se de quando trabalhará nas construções da barra da Tijuca. O engenheiro chegava sempre depois do meio dia com o maior mulherão no carro e nem um bom dia dava para a peãozada. Saía dando esporro em todo mundo só para crescer na frente da mulher, e o babaca do encarregado, só porque arrumara uma merrequinha a mais, vivia puxando o saco do maldito. Seria-bicho solto mesmo. Nunca marcaria zero hora pros samangos. Haveria de estourar a boa pra poder comprar uma chácara no interior, viver o resto da vida criando galinhas numa boa (LINS, 2002, p. 118).
\end{abstract}

Martelo, apesar de revoltado, tinha medo de algum dia ser morto pela bandidagem ou ser preso pela polícia. Em um assalto com Inferninho, sofreu uma difícil perseguição da polícia, e então começou a refletir sobre a sua vida. Na volta para casa, ao passar em frente a uma igreja, escutou o discurso do pastor, as palavras tocaram sua alma, e assim converteu-se, a sua alegria era bastante grande, pois agora pensava que seria mais feliz. Vejamos esse fato na narração de Lins:

O cristão mudou-se, sem se despedir dos amigos, um mês depois da visita dos religiosos. Largou baralho, canivete, o revólver, os vícios. De uma vez por todas deixou de lutar contra o azar. Volta e meia dizia para Cleide que ele sim tinha arrebentado a boa. Conseguiu um emprego na empresa Sergio Dourado, onde foi explorado por muito tempo, mas não ligava. A fé afastava o sentimento de revolta diante da segregação que sofria por ser negro, desdentado, semi analfabeto. Os preconceitos sofridos partiam dessa gente que não tem Jesus no coração (LINS, 2002, p. 129-130). 
Os bandidos da Cidade de Deus ficaram inconformados com Martelo, pois ele saiu do conjunto sem se despedir. Parece que a religião e a fé "afastavam o sentimento de revolta diante da segregação que sofria por ser negro". Tinha a consciência de que o preconceito partia de quem não tinha fé. Inferninho era um dos melhores amigos do marido de Cleide. Depois da conversão do amigo, Inferninho foi ao encontro de Luís Ferroada para combinar novos assaltos. Luís Ferroada havia acabado de fugir da prisão e era visto como um bandido perigoso, devido ao fato de, com seus vinte anos de idade, já ter matado mais de trinta pessoas. Como veremos na citação a seguir, Ferroada apresentava um olhar negativo em relação aos brancos. Vejamos essa situação nas palavras de Lins, quando este narra os planos dos bandidos para o assalto de postos de gasolina.

\begin{abstract}
Na sexta-feira seguinte, iriam antes da meia-noite para assaltar dois postos de gasolina na Estrada dos Bandeirantes e um no Largo da Taquara. Sandro Cenourinha teve que disputar na porrinha com Madrugadão para poder ser o motorista da operação. Ferroada não aliviava nenhuma das vítimas. Mesmo se elas não oferecessem reação, o bandido dava tiro na bunda, coronhadas e tapas na cara. A única que esboçou reação levou chumbo na cabeça. $O$ assaltante não gostava de branco bem arrumado. Achava que eles tomavam o lugar do negro em tudo. Até mesmo na Baixada Fluminense, e agora no conjunto, quando via um branco bem arrumado, assaltava, cometia violências para vingar o negro que teve seu lugar roubado na sociedade. Não era bandido de correr da polícia, achava que isso era atitude de neguinho bunda - mole. "já deitei um monte de samango que se meteu no meu caminho', dizia sempre que a ocasião era propícia" (LINS, 2002, p.132).
\end{abstract}

Os bandidos, como Ferroada, agiam de forma ativa e violenta para com os brancos, buscando "vingar o negro que teve seu lugar roubado na sociedade". Contra os preconceitos raciais, suas formas de reação eram baseadas em assaltos, crimes e violência, mas um fato distinto chama bastante a atenção, quando Lins narra a forma de pensar de um senhor, que acreditava na luta armada e na força do povo. O personagem se denominava marxista-leninista e ocupava a cena em que Lins narra a vida do personagem Inho. Inho, desde menino, já era ativo na vida do crime. Com muita insistência, a mãe do garoto o convenceu a trabalhar como engraxate. Foi então que encontrou o senhor marxista. Vejamos o que nos diz Lins quando a mãe de Inho agradece a cadeira de engraxate gratuita:

Minha senhora, fique sabendo que eu não sou bondoso, muito menos acredito em Deus, eu sou é marxista - leninista. Acredito na força do povo, no movimento de base, na organização do proletariado, e vou mais longe eu acredito na luta armada. Acredito numa ideologia e não no Deus da igreja católica que é usado para acalmar o povo, fazer o trabalhador de cordeiro. Aposto que essa patroa da comadre da senhora ai é católica, mas porque ela não deixava a sua comadre levar o menino na escola? Porque não ajudar direitinho, conforme a senhora mesmo disse ai? A senhora tem que ser marxista - leninista, ajudar a 
conscientizar esse povo pra gente tomar o poder... a senhora não vê o que fizeram com a gente? Colocaram nós aqui nesse fim de mundo, nessas casinhas de cachorro... Essa rede de esgoto malfeita que já ta dando entupimento, não tem ônibus, não tem um hospital, não tem nada... nada. Tem é cobra subindo pelo ralo, lacraias e ratos passeando pelo telhado. Temos que nos organizar! (LINS, 2002, p.157).

Lins retrata um personagem politizado. Consciente do poder do povo marginalizado. Consciente da condição subumana que instituições e autoridades oficiais impunham à população proletária. Consciência que vê na organização uma forma de reivindicação da igualdade. No entanto, o romance de Lins mostra uma igualdade de miséria, de exclusão e de preconceito que, ao invés de uni-los, parece cada vez mais segregá-los. A própria comunidade teme os bandidos. E é pelo medo que a comunidade se resigna aos criminosos.

Os policiais descritos por Lins também apresentavam preferências de cor. A citação a seguir se refere à diminuição dos dias na cadeia, quando se tratava de brancos. Manguinha, devido ao fato de ser branco, dizia ser apenas um viciado, sendo os afrodescendentes maconheiros. A esse respeito Lins narra:

\footnotetext{
Numa noite de quarta-feira, Manguinha afirmou para os amigos que iria sacudir umas cachangas com dois parceiros Tiãozinho e Coca-cola, que ele conhecera nos cinco dias em que ficará preso na Delegacia de Entorpecentes por estar com duas trouxas de maconha na cueca no centro da cidade. Os policiais acharam por bem deixá-lo de molho na cadeia para ver se ele tomava jeito. A polícia tinha o costume de agir assim com os viciados brancos. Até mesmo na favela, os brancos, quando não fossem nordestinos tinham certa regalia se flagrados fumando maconha. Na maioria das vezes, os policiais nem os prendiam, davam somente alguns conselhos, os libertando em seguida. Graças a esse salvo conduto, Manguinha dizia que maconheiros eram os pretos, ele era apenas um viciado (LINS, 2002, p. 255).
}

Os preconceitos e os estigmas permeiam todas as situações cotidianas nos personagens elencados por Lins. Fosse morador da comunidade, trabalhador, policial ou criminoso, todos pareciam submetidos à condição da cor, que serve como fator determinante para justificar vinganças, violências e demais atrocidades. Nesse universo, as relações sociais perdem, em detrimento das individuais.

\section{Considerações finais}

A interdisciplinaridade, envolvendo a história e a literatura, foi fundamental para compreendermos a problemática racial existente na comunidade analisada do Rio de Janeiro. Por meio da obra literária de Lins, desvendamos inúmeros aspectos da realidade da população descrita, bem como de seu espaço e de sua temporalidade, um tema de 
grande relevância social e histórica. Os estereótipos raciais, presentes na comunidade, foram discutidos a partir das entrelinhas do romance, seus personagens são pessoas insatisfeitas com a realidade, que, desde crianças, enfrentam os mais diversos tipos de discriminações, sendo a miséria responsável, na maioria das vezes, pelo abandono dos estudos e pela entrada na vida do crime.

Percebemos que o preconceito racial não é um problema do século $X X I$, mas resultado de anos de desvalorização do afro-brasileiro. A partir da dramatização apresentada por Lins, os personagens manifestavam suas revoltas contra a sociedade excludente e racista, revelando subjetividades, sentimentos e emoções. Nesse contexto, acreditamos na importância de se discutir esse tema, pois a cor não poderia ser tida como um sinal de superioridade ou inferioridade de um indivíduo perante o outro. Percebe-se, assim, que as páginas descritas por Lins desconstroem o mito de democracia racial existente no Brasil. Mito que encobre as violências e os assassinatos, que fazem do Brasil um dos países mais violentos do mundo.

As situações de preconceitos estão implícitas nas mais variadas formas, na medida em que essas pessoas são vistas como perigosas, marginais, ociosas, frente à sociedade em geral. Em relação aos direitos iguais, há muito tempo exigidos pelos afrodescendentes, analisemos as palavras de King, quando se encontrava preso em Birmingham, nos Estados Unidos, por realizar uma passeata. Na carta, ele responde ao clero da região em defesa dos afrodescendentes:

Sabemos por meio de experiências dolorosas que a liberdade nunca é voluntariamente concedida pelo opressor; ela tem de ser exigida pelo oprimido. Francamente, ainda não tomei parte em uma campanha de ação direta que fosse 'oportuna' na visão daqueles que não sofreram indevidamente da doença da segregação. Já faz anos que ouço a palavra 'Espere!' Ela ressoa nos ouvidos de cada negro com uma familiaridade aguda. Esse espere quase sempre significou 'nunca'. Temos de chegar a percepção, junto com um de nossos eminentes juristas, de que 'a justiça adiada por muito tempo é justiça negada' (KING JR, 1963).

Podemos pensar, a partir das palavras de King, a realidade da comunidade descrita no romance "Cidade de Deus". O oprimido, no caso, os habitantes, precisam exigir seus direitos frente à sociedade, mas, quando essa sociedade não atende aos seus clamores, então eles lutam de formas ilegais. Assim sendo, nota-se a falta de preocupação ou a justiça negada a essas pessoas, na maioria das vezes, desprovidas dos principais meios de subsistência.

A escrita poética e realista do autor auxilia os leitores no desenvolvimento de análises críticas, promovendo formas diversas de conscientização sobre as causas que 
levam esses habitantes a traficar, a matar e a roubar. A pesquisa realizada com essa fonte, além de fornecer um riquíssimo conteúdo sobre a violência do racismo no Rio de Janeiro, auxiliou-nos na compreensão dos aspectos históricos presentes na ficção. Nessas circunstâncias, destrói-se o mito de que as obras de cunho literário são baseadas somente na imaginação de quem escreve, pois quem narra é imbuído de aspectos do cotidiano, que refletem acontecimentos da época e do espaço. 


\section{Referências}

ADAN, C. F. F. A literatura como evidência histórica: Cotidiano Popular em o Cortiço. Revista de História e Estudos Culturais, ano V, n. 3, 2008.

BARCELLOS, C. Organização Espacial, Saúde e Qualidade de vida. In: Seminário Nacional saúde e Ambiente no Processo de Desenvolvimento. 2. ed. Rio de Janeiro: Fundação Oswaldo Cruz, 2000.

BORGES, V. R. História e Literatura: Algumas Considerações. Revista de Teoria da História, ano 1, n. 3, jun. 2010.

CHALHOUB, S.; PEREIRA, L. A. de M. Apresentação. In: CHALHOUB, S.; PEREIRA, L. A. de M. (Org.). A história contada: capítulos de História social da Literatura no Brasil. Rio de Janeiro: Nova Fronteira, 1998. p. 7-13.

COSTA, J. F. Da cor ao corpo: A violência do racismo. Rio de Janeiro: Edições Graal. 1984.

KING JR, M. L. Parte da carta de uma prisão em Birmingham, em 16 de abril de 1963. Disponível em: <http://www.ordemlivre.org/textos/477/>. Acesso em: 12 maio 2013.

LEMAIRE, R. Pelas Margens: Outros caminhos da História e da Literatura. Campinas; Porto alegre: Edição da Unicamp, 2000.

LINS, P. Cidade de Deus. São Paulo: Companhia das Letras, 2002.

PESAVENTO, S. J. História: Fronteiras. São Paulo: Humanitas; Anpuh, 1999.

O mundo como texto: Leituras da História e da Literatura. História da Educação, Pelotas, n. 14, set. 2003.

SARMENTO, R. Cidade de Deus: A realidade exposta na literatura e no cinema. Todas as Musas, ano 2, n. 2, jan./jun. 2011.

SANTOS, A. M.; LIMA, C. M. A contribuição da economia solidária para o desenvolvimento local em Cidade de Deus. VI Congresso Português de Sociologia, Mundos Sociais Saberes e Práticas. Universidade Nova de Lisboa Faculdade de Ciências sociais e humanas, n. 575, 2008.

WEBER, A. de V. A Apropriação do espaço produzindo uma cartografia: A favela e diferentes formas de classificação de espaço. Vivência, Rio Grande do Norte, v. 29, p. 273-287, 2005.

WHITE, H. Trópicos do Discurso: Ensaios sobre a Crítica da Cultura. 2. ed. São Paulo: Editora da Universidade de São Paulo, 2001.

Artigo:

Recebido em: 20/03/2013

Aceito em: 27/06/2014 